\title{
Expert-Based Maps as a Regional Planning Tool Supporting Nature Conservation and Production-Integrated Compensation-A German Case Study on Biodiversity Offsets
}

\author{
Christian Sponagel ${ }^{1, * \mathbb{D}}$, Andre Raichle ${ }^{2}$, Martin Maier ${ }^{3}$, Susanne Zhuber-Okrog ${ }^{4}$, \\ Ulrike Greifenhagen-Kauffmann ${ }^{5}$, Elisabeth Angenendt ${ }^{1}$ and Enno Bahrs ${ }^{1}$ (i)
}

1 Department of Farm Management (410b), Institute of Farm Management, University of Hohenheim, Schwerzstraße 44, 70593 Stuttgart, Germany; Elisabeth.Angenendt@Uni-Hohenheim.de (E.A.); bahrs@Uni-Hohenheim.de (E.B.)

2 Raichle-Ecology, Stahlbrunnstraße 20, 73266 Bissingen an der Teck, Germany; a.raichle@raichle-ecology.de

3 Flächenagentur Baden-Württemberg GmbH, Gerhard-Koch-Straße 2, 73760 Ostfildern, Germany; maier@flaechenagentur-bw.de

4 Naturschutzbund Deutschland (NABU) Stuttgart e. V., Charlottenplatz 17, 70173 Stuttgart, Germany; susanne.zhuber-okrog@NABU-Stuttgart.de

5 Landwirtschaft/Grundstücksverkehr, Liegenschaftsamt, Landeshauptstadt Stuttgart, Heustraße 1, 70174 Stuttgart, Germany; Ulrike.Greifenhagen-Kauffmann@stuttgart.de

check for updates

Citation: Sponagel, C.; Raichle, A.;

Maier, M.; Zhuber-Okrog, S.;

Greifenhagen-Kauffmann, U.; Angenendt, E.; Bahrs, E. Expert-Based Maps as a Regional Planning Tool Supporting Nature Conservation and Production-Integrated

Compensation-A German Case Study on Biodiversity Offsets. Land 2021, 10, 808. https://doi.org/ 10.3390/land10080808

Academic Editors: Stephan Bartke and Sigrun Kabisch

Received: 15 July 2021

Accepted: 30 July 2021

Published: 1 August 2021

Publisher's Note: MDPI stays neutral with regard to jurisdictional claims in published maps and institutional affiliations.

Copyright: () 2021 by the authors. Licensee MDPI, Basel, Switzerland. This article is an open access article distributed under the terms and conditions of the Creative Commons Attribution (CC BY) license (https:// creativecommons.org/licenses/by/ $4.0 /)$.
* Correspondence: Christian.Sponagel@Uni-Hohenheim.de

Abstract: Many countries worldwide have developed guidelines for offsetting impacts on nature and landscape. Suitable locations are the prerequisite for the implementation of these measures, and this might lead to conflicts with agriculture. In addition, comprehensive planning is often lacking and potential added values for nature conservation are not exploited. Concepts such as the so-called production-integrated compensation (PIC) have been introduced to give farmers the opportunity to actively participate in the offsetting process and improve cooperation. However, up to now, PIC has only rarely been put into practice. Against this backdrop, we have developed a regional planning tool for the implementation of PIC in practice. Based on geodata such as soil data, agricultural structure, or natural conditions at the field and landscape level, the general suitability, and specific measure-based recommendations for each plot can be verified with the help of a decision support system. These factors are assessed from both a nature and an agricultural perspective. The goal here is to highlight synergy effects and increase the likelihood of the proposed measures being implemented. Our tool facilitates the integrated planning of biodiversity offsets at regional level. In this way, it can promote the bundling and networking of measures. However, on-site analyses should be undertaken to complement the implementation of measures.

Keywords: biodiversity offsets; offset implementation; production-integrated compensation; nature conservation; landscape planning; agri-environmental policy

\section{Introduction}

Land taken up by settlement and infrastructure development is one of the major drivers of biodiversity loss [1-3]. As part of their so-called "no-net-loss" policies, many countries around the world have implemented regulations for offsetting impacts on nature and landscapes $[4,5]$. In Germany, this is anchored in the Nature Conservation Law $(B N a t S c h G)$ in what is known as the "Impact Mitigation Regulation" (IMR) and follows a polluter pays principle [6]. Offsetting is actually the last step in the mitigation hierarchy after avoiding or minimizing impacts on nature and landscapes [7]. The requirement for offsetting is usually linked to various related questions, for instance, where and how offset measures can be conducted in the most efficient and effective manner from an ecological 
perspective [8,9]. Hence, in addition to the land taken up by impacts, further land is required for the implementation of offset measures [10].

In contrast to strategic planning on a regional level, randomly available sites are often taken up for offsetting [11]. Hence, potential added values for nature conservation generated by pooling and networking measures are often not exploited. In addition, there may be land use conflicts with agriculture as farmland is frequently used for biodiversity offsets $[10,12]$. Despite this, agriculture in particular could be a potential and important partner in nature conservation, as it occupies the largest area of land in Germany [13]. It is therefore an important stakeholder in biodiversity offsetting [14-17]. Concepts such as the so-called production-integrated compensation (PIC) have been introduced to give farmers the chance to actively participate in the offsetting process, and to improve cooperation between nature conservation and agriculture [18-20]. In general, there is no one single definition of PIC. However, PIC can be broadly defined as management or maintenance measures as set out in Article 15 (3) BNatSchG on agricultural and forestry land with continued agricultural and forestry use. It leads to a permanent enhancement of nature or landscapes. However, it is not always possible to clearly distinguish PIC measures from other offset measures on agricultural land in individual cases. In addition to the type of measure, individual farm conditions play a role here. For example, the creation of a meadow orchard or the conversion of arable land into grassland may well be a PIC measure for an individual farm if it fits into the farm concept. For other farms, however, this would not constitute a PIC measure as they would not be able to derive a monetary return from the land.

In general, one goal of PIC is to minimise the loss of agricultural productivity and to preserve agricultural land use [18]. In particular, measures that only take up a small area of a parcel of land and yet lead to an upgrading of the entire area would count as PIC. Therefore, the following conditions should be met from our perspective, according to Mössner [21], to address PIC from an agricultural angle:

I. The measures are implemented in a consensus with agriculture.

II. There is still a monetary return from agricultural land through production.

III. Both forms of "land sparing" and "land sharing" are possible, i.e., spatial separation between extensification and intensification or extensification and production on the same area (e.g., flower strips and extensive cultivation of cereals).

Especially in metropolitan areas, the multifunctionality of agriculture takes on a special significance [22]. In addition to the production of high-quality food, the emphasis is also on the cultivation of cultural landscapes. It is precisely here that PIC could also contribute directly to the diversity of nature and landscapes as a recreational area for the population in a conurbation [23]. Agriculture also recognises the need of these groups especially in these peri-urban areas. Consequently, PIC could also generate added value in the context of social recognition [24]. From a political point of view, the topic of biodiversity and agriculture is currently very much on the agenda and is shaped at EU level by the EU Biodiversity Strategy [25] or the EU Farm-to-Fork Strategy [26]. The main objectives include strengthening protected areas and reducing the use of plant protection products. The political demands, therefore, also present a challenge for many farms from an economic point of view [27]. At this point, PIC measures could, of course, also offer economic options that enable synergies to be tapped into. By means of the guaranteed maintenance of the measures, nature conservation could also benefit from PIC [28]. According to a study by Rabenschlag et al. [29] in Baden-Württemberg, there are often many deficits in the implementation of biodiversity offsets at the present time.

However, production-integrated compensation measures are rarely implemented in practice [21]. As far as agriculture is concerned, PIC measures are particularly in demand and could be expanded in the future [30]. There is often a lack of information and on-site communication, as well as a general lack of overarching planning [30]. In the field of nature conservation and ecosystem services, expert-based assessment approaches using geodata have been used to map the potential for specific ecosystem services [31] or green 
infrastructure planning [32], for example. Against this backdrop, we have developed a regional planning map as a tool for promoting PIC in the Stuttgart Region in the German state of Baden-Württemberg based on expert knowledge. In this context, we primarily proceeded from the hypothesis that there may be synergy effects between nature conservation objectives and agricultural interests. This is based on previous studies which have shown that farmers are indeed willing to implement voluntary measures under certain conditions $[16,19]$.

Based on available and suitable geodata for soil conditions, agricultural structure, protected areas, etc., various PIC options have been evaluated at the field level to derive specific recommendations for offset measures. In this context, we focus on measures on arable land and grassland. Both agricultural and nature conservation perspectives were taken into account in order to elucidate the effectiveness and likelihood of implementation. In addition, potential synergy effects have been identified to promote the networking and bundling of measures. This means that our regional map for PIC could be a relevant aid for decision-makers at the municipal level when planning offset measures and could serve as a basis for constructive discussions with farmers. Hence, measures that appear to make sense for both agriculture and nature conservation can be selected.

\section{Characterisation of the Study Area}

The Stuttgart Region is one of the strongest economic regions in Germany with a high volume of land taken up for settlement and transport infrastructure development $[33,34]$. It accounts for approximately $10 \%$ of the total area of Baden-Württemberg. Moreover, $16 \%$ of the total land use for settlement and transport infrastructure in Baden-Württemberg was earmarked here between 2000 and 2016 [35]. Therefore, offsetting is an important factor in this region.

In total, the utilised arable land (UAA) in the Stuttgart Region amounts to approximately 133,766 ha according to the 2019 dataset of the Integrated Administration and Control System (IACS), which was provided by the Baden-Württemberg Ministry of Rural Affairs and Consumer Protection. About 54\% of this is arable land (ARA) and 38\% grassland. The remaining area consists of vineyards and permanent crops. There are major spatial disparities in the region's agricultural structure. Whereas the districts Böblingen and Ludwigsburg are dominated by arable farming, the eastern districts Rems-Murr-Kreis and Göppingen have a high proportion of grassland. Especially in the urban district of Stuttgart, specialty crops, such as fruits and vegetables, are cultivated on more than $10 \%$ of the arable land (Figure 1).

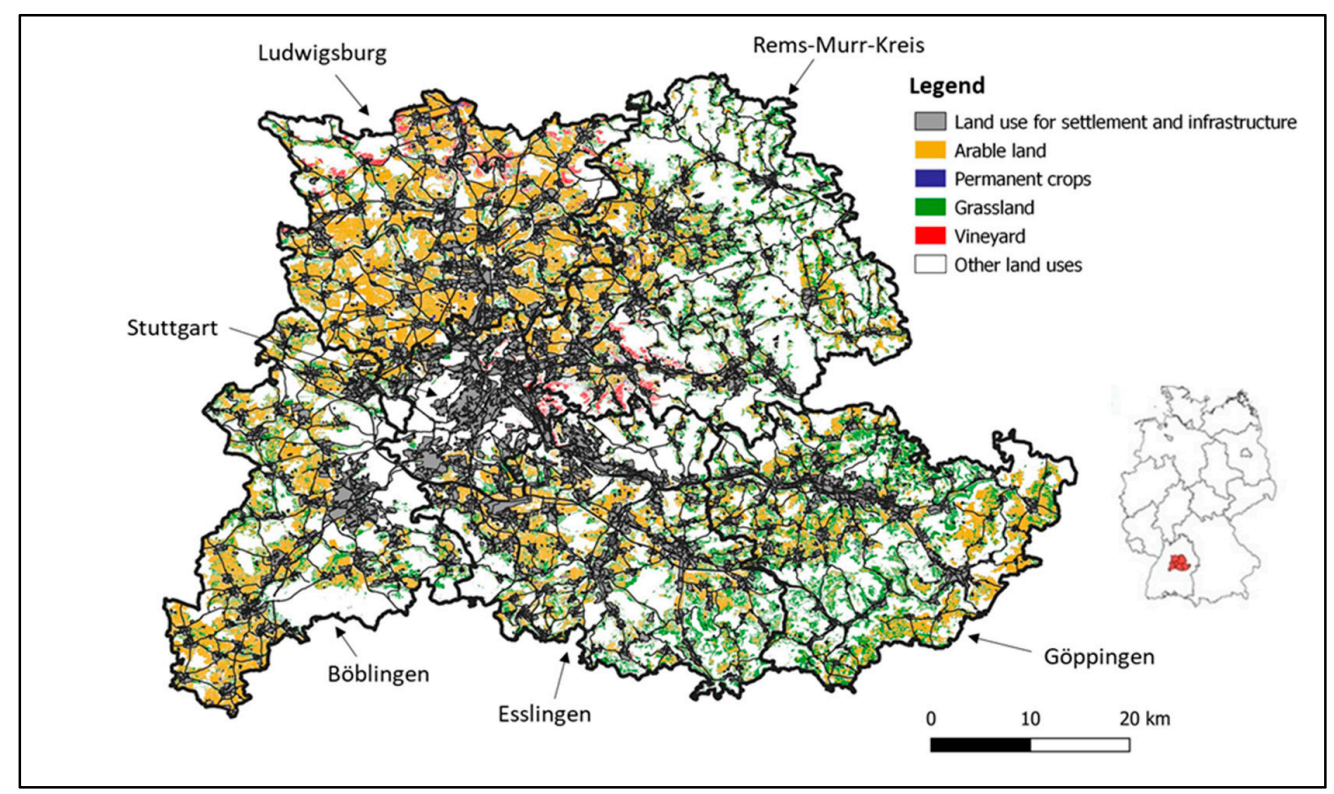

Figure 1. Land use in the Stuttgart Region based on IACS data and BKG [36] and Verband Region Stuttgart [37]. 


\section{Material and Methods}

\subsection{General Procedure and Input Data for the Regional Map}

The site-specific selection of measures plays a major role in the successful implementation of PIC measures [23]. Therefore, both nature conservation and agricultural concerns must be taken into account. For example, a measure may be appropriate and prudent from a nature conservation point of view on the one hand, but acceptance by agriculture may be low on the other. As a result, the likelihood of implementing the measure may be limited. Therefore, in the following, the interfaces between nature conservation and agricultural concerns in the compensation process are examined on the regional level. Figure 2 gives an overview of the entire approach and process that was used to draw up the regional map for the implementation of PIC measures on agricultural land. The aim is to derive recommendations for PIC measures at the plot level. To this end, the immediate surroundings of a plot (field level) and the wider spatial environment (landscape level) are taken into account. In this context, plots mean the arable and grassland plots taken from the IACS dataset. Beside the IACS dataset also agricultural statistical data was used regarding the agricultural perspective. This data is based on the so-called Agrarstrukturerhebung in Germany. This is a nationwide and regularly conducted survey of farms on farm structure, land use, and livestock production, etc. [38].

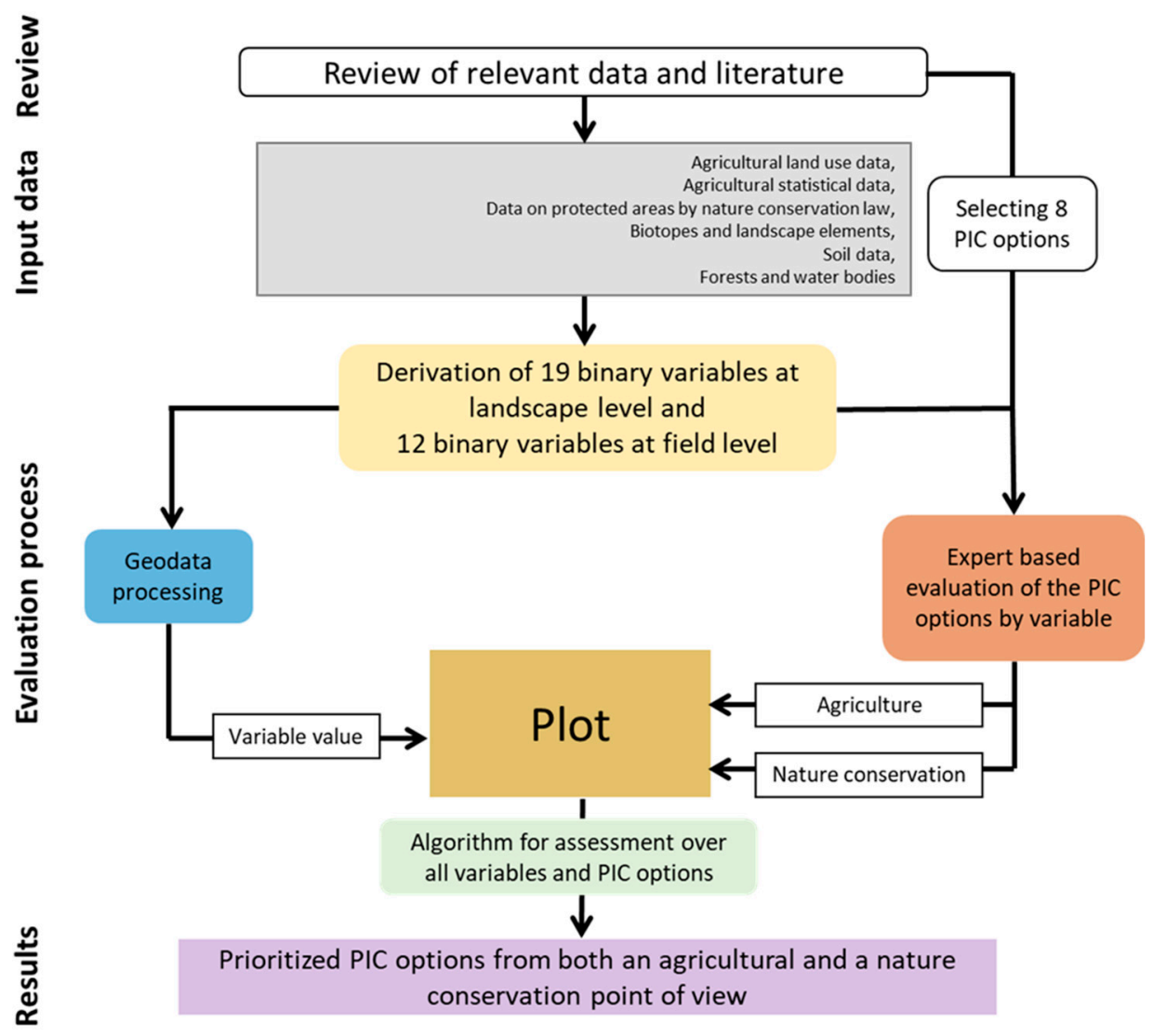

Figure 2. Overview of the entire approach and process of the development of a regional map for PIC measures.

\subsection{PIC Options Considered for the Regional Map}

Basically, there are numerous proposed measures for PIC that needed to be discussed at the outset $[18,23,39,40]$. Based on the literature review carried out in this context, 14 potential and typical PIC measures were initially identified, and a description was provided for the model (Table 1). 
Table 1. Overview of the selected PIC measures and their description.

\begin{tabular}{cc}
\hline PIC Measure & Description \\
\hline Temporary Greening & $\begin{array}{c}\text { Temporary greening is carried out, for instance, of } \\
\text { tramlines using a flower mixture in the tramline width } \\
\text { of usually } 2.50 \mathrm{~m} \text { to } 3.00 \mathrm{~m} \text {. Fertilisers may be used on } \\
\text { these tramlines but not pesticides. }\end{array}$ \\
\hline A system of annual/perennial flower strips is \\
developed to ensure that sufficiently developed flower \\
strips are always available. Before a flowering strip is \\
removed, a new flowering strip is planted with \\
sufficient lead time to ensure that the habitat \\
characteristics of the flowering strips are \\
uninterrupted. If, due to crop rotation, it is not \\
possible to establish new flowering strips with annual \\
flowering strips in advance, individual flowering \\
strips must be left for 1.5 to 2 years. The continuous \\
presence of flowering strips enables them to serve as a \\
refuge for several species in the field.
\end{tabular}

Permanent flowering strips or areas are established on arable land, each of which makes up only a small part of the arable field. This can be done along paths and field edges, for example, where the flower strips are

Permanent Flower Strips and Areas established as green bands. Regular re-establishment takes place (e.g., every 3 to 5 years). In order to regulate undesirable plant species, annual planting can also be undertaken from time to time as an exceptional measure.

This is arable fallow land with self-vegetation and annual mowing, but no removal. In addition, no Fallow Land fertilisers or pesticides are used. Fallowing is done in rotation with a standing time of 3-5 years on one area.

A field is only cultivated extensively on a permanent basis. Pesticides and synthetic fertilisers are no longer used. Reduced mechanical weed control and organic fertilisation are possible.

Extensive Used Arable Land

Seeds are sown with wider or double seed row spacing, for instance $25-30 \mathrm{~cm}$. This encourages the growth of wild herbs on the field. This measure is carried out in rotation in accordance with the crop rotation.

In the cereal crop, about 5-6 lark windows per ha are created, each at least $25 \mathrm{~m}^{2}$ in size. The usual use of fertilisers and pesticides is maintained.

In an arable field, individual sites with low yield but high conservation potential (e.g., wet sites, small water

Infield Nature Protection Spots bodies, dry knolls) are removed from agricultural land use.

After the grain harvest, the stubble is left on the field at a height of about $20 \mathrm{~cm}$ until at least February. Fertilisation and synthetic chemical pesticides are used during the growing season of the arable crop. In the period from harvest to February there is no fertilisation, no use of plant protection products and no mechanical weed control. 
Table 1. Cont.

\begin{tabular}{cc}
\hline PIC Measure & Description \\
\hline Unharvested Strips of Cereals & $\begin{array}{c}\text { A portion of a crop is not harvested, but is left on the } \\
\text { field until at least February. It serves as a food base or } \\
\text { refuge for specific species such as field hamsters. No } \\
\text { synthetic fertilisers or pesticides are used in this area. }\end{array}$ \\
\hline Reduced Tillage & $\begin{array}{c}\text { Only greatly reduced tillage is used, i.e., usually no-till } \\
\text { and little tillage before and after harvest. }\end{array}$ \\
Conversion of Arable Land into & $\begin{array}{c}\text { Arable land is converted into extensively used } \\
\text { grassland. The use of synthetic fertilisers and } \\
\text { pesticides is avoided. There is at least one annual } \\
\text { mowing with removal. }\end{array}$ \\
Extensification of Grassland & $\begin{array}{c}\text { A permanent grassland area is only used extensively, } \\
\text { i.e., no fertilisers or pesticides are used. In addition, } \\
\text { strips of old grass are left when mowing. }\end{array}$ \\
\hline Uncut Hay Meadow Strips & $\begin{array}{c}\text { In meadows, individual strips are left out during the } \\
\text { first mowing. These strips of old grass, about } 6 \text { m } \\
\text { wide, are then mown from mid-June at the earliest. }\end{array}$ \\
\hline
\end{tabular}

Some measures do show similarities with regard to the site conditions. The measures have, therefore, been grouped into a total of eight PIC options for evaluation in the map. In this context, all measures relating to the extensification of arable land or grassland use were combined in each case. Table 2 gives an overview of how the individual measure were grouped in the options.

Table 2. Grouping of the measures in PIC options.

\begin{tabular}{cc}
\hline PIC Measure & PIC Option \\
\hline Greening & Greening \\
Annual flower strips & Flower strips \\
Permanent flower strips & Permanent flower strips \\
Fallow land & Fallow land \\
Extensively used arable land & Extensive arable farming \\
Skylark windows & Extensive arable farming \\
Infield nature protection spots & Extensive arable farming \\
Stubble fallow & Extensive arable farming \\
Unharvested strips of cereals & Extensive arable farming \\
Reduced tillage & Reduced tillage \\
Conversion of arable land into grassland & Grassland \\
Extensification of grassland & Extensification of grassland \\
Uncut hay meadow strips & Extensification of grassland \\
\hline
\end{tabular}

\subsection{Description of Data Input and Processing}

Based on a review of relevant and available data, 19 variables were derived at the landscape, i.e., the municipal level, and 12 variables at the field level (Tables 3 and 4). From the perspective of nature conservation, special attention was paid to protected areas under nature conservation law and elements of the biotope networks that may be especially relevant for PIC [23]. From an agricultural perspective, the agricultural structure, for instance the share of grassland or arable land in the utilised agricultural area per municipality or the share of specific crops, such as specialty crops, that also reflect agricultural opportunity costs, for example, were some of the criteria considered [41].

The variables were then treated as binary variables, i.e., a specific characteristic is present or not. Certain limits were set for each variable on the municipal or field level based on expert knowledge. The definition of these limits at municipal level was based on the typical values in the Stuttgart Region. The selected values are predominantly 
above the median for all municipalities. For the proportion of grassland at the municipal level, this limit was set at $50 \%$, for example. If a municipality exceeds this proportion, the characteristic of a high proportion of grassland in the municipality is met at the landscape level.

Table 3. Variables used to create the PIC map at the landscape, i.e., municipal level.

\begin{tabular}{cc}
\hline Variables & Source of the Data \\
\hline Share of grassland $(>50 \%)$ & IACS dataset 2019 \\
Share of specialty crops on arable land $(>5 \%)$ & IACS dataset 2019 \\
Share of cereals in the crop rotation $(>60 \%)$ & IACS dataset 2019 \\
Share of root crops in the crop rotation $(>10 \%)$ & IACS dataset 2019 \\
Share of cattle $(>1 \mathrm{GV} * /$ ha grassland + forage crops) & IACS dataset 2019; Statistisches Landesamt [42] \\
Share of dairy cows $(>0.5 \mathrm{GV} /$ ha grassland + forage crops) & IACS dataset 2019; Statistisches Landesamt [42] \\
Share of AEMs ** on arable land $(>10 \%)$ & IACS dataset 2019 \\
Share of AEMs on grassland $(>20 \%)$ & IACS dataset 2019 \\
Share of organic farming on arable land $(>10 \%)$ & IACS dataset 2019 \\
Share of organic farming on grassland $(>10 \%)$ & IACS dataset 2019 \\
Share of arable land in nature conservation areas $(>0.5 \%)$ & IACS dataset 2019; BfN [43] \\
Share of grassland in nature conservation areas $(>2 \%)$ & IACS dataset 2019; BfN [43] \\
Share of arable land in Special Protection Areas $(>10 \%)$ & IACS dataset 2019; BfN [44] \\
Share of grassland in Special Protection Areas $(>20 \%)$ & IACS dataset 2019; BfN [44] \\
Share of arable land in FFH *** areas $(>2 \%)$ & IACS dataset 2019; BfN [45] \\
Share of grassland in FFH areas $(>10 \%)$ & IACS dataset 2019; BfN [45] \\
Share of arable land in landscape protection areas $(>25 \%)$ & IACS dataset 2019; BfN [46] \\
Share of grassland in landscape protection areas $(>40 \%)$ & IACS dataset 2019; BfN [46] \\
Share of grassland in legally protected biotopes $(>0.5 \%)$ & IACS dataset 2019
\end{tabular}

${ }^{*}$ livestock unit (1 GV equals $500 \mathrm{~kg}$ live weight); ${ }^{* *}$ Agri-environmental measures; ${ }^{* * *}$ Flora-Fauna-Habitat areas as defined in the European Union's Habitats Directive (92/43/EEC).

Table 4 gives an overview of the selected variables at field level. As is the case of the landscape level, a characteristic of the plot, such as high soil quality, is either present or absent. This was defined by the intersection of the plot polygons and the respective geodata layer, for instance the soil map using ArcGIS [47]. Some variables at field level were defined by the distance in meters between the respective plot and forest, biotopes, landscape elements, etc. Plots within areas protected under nature conservation law were identified, i.e., a distance of zero meters. For this purpose, the distances between the polygons of the plots and the selected geodata features were analysed using the "Near" Tool in ArcGIS [47]. The outlines of the plots were taken from the Integrated IACS 2019 dataset.

Table 4. Binary variables used to create the PIC map at field level.

\begin{tabular}{|c|c|c|c|}
\hline \multirow{2}{*}{ Variables at Field Level } & \multicolumn{3}{|c|}{ Description of the Data } \\
\hline & Source & Attribute & Attribute Level \\
\hline Forest $(\leq 20 \mathrm{~m}$ distance $)$ & ALKIS [48] & GISELANAME & Forest \\
\hline Water bodies ( $\leq 20 \mathrm{~m}$ distance) & LUBW [49] & Stream network & \\
\hline Biotopes ( $\leq 20 \mathrm{~m}$ distance) & IACS dataset 2019 & IACS code & $924 *, 925 *$ \\
\hline $\begin{array}{l}\text { Woody structures } \\
(\leq 20 \mathrm{~m} \text { distance })\end{array}$ & ALKIS [48] & GISELANAME & $\begin{array}{l}\text { Field copse, field boundary, } \\
\text { grove, hedge }\end{array}$ \\
\hline \multirow{2}{*}{$\begin{array}{l}\text { Wetland areas } \\
(\leq 20 \mathrm{~m} \text { distance })\end{array}$} & ALKIS [48] & GISELANAME & $\begin{array}{l}\text { Pond, wetland, grassland, } \\
\text { wetland; }\end{array}$ \\
\hline & LUBW [50] & Core area & \\
\hline Dry areas ( $\leq 20 \mathrm{~m}$ distance) & LUBW [51] & Core area & \\
\hline Soil quality (low) & LGRB [52] & Soil fertility & $1.0,1.5$ \\
\hline Soil quality (high) & LGRB [52] & Soil fertility & $3.0,3.5,4.0$ \\
\hline $\begin{array}{c}\text { Within nature conservation } \\
\text { area (yes) }\end{array}$ & BfN [43] & BfN_ID & \\
\hline
\end{tabular}


Table 4. Cont.

\begin{tabular}{cccc}
\hline Variables at Field Level & Source & Description of the Data & Attribute Level \\
\cline { 2 - 4 } $\begin{array}{c}\text { Within Natura 2000 network } \\
\text { (yes) }\end{array}$ & BfN [45]; BfN [44] & Attribute & BfN_ID \\
$\begin{array}{c}\text { Groundwater and backwater } \\
\text { up to 1 m depth (yes) }\end{array}$ & LGRB [52] & GRUSTAWR \\
Risk of soil erosion (yes) & LGRB [53] & $\begin{array}{c}\text { Mean long-term soil erosion } \\
\text { in t/ha/year }\end{array}$ & $>2$ \\
\hline
\end{tabular}

* Agriculturally used and unused biotopes.

\subsection{Assessment of the PIC Options According to the Variables}

For each field or grassland plot, 31 binary variables are available at the municipal and at the plot level. The respective eight PIC options were evaluated at the municipal and field level in an assessment matrix. It was then decided, from a nature conservation and agricultural perspective, whether a PIC measure is desirable or rather not desirable for a certain expression of a variable. For this assessment, an expert group consisting of three people each from the field of nature conservation and agriculture was formed. The experts in the field of nature conservation were recruited from both local stakeholders (non-governmental organisations) and people who are active as experts in the field of planning offset measures in the Stuttgart Region having specific local knowledge. The agricultural experts came from academia and local administration, i.e., they also have specific local knowledge.

Hence, $248(8 \times 31)$ combinations of PIC options and variables were evaluated twice from the agricultural and nature conservation point of view, i.e., 496 decisions in total (Table S1 in the supplementary material). The evaluation was made in each case in four integer levels from +1 (desirable) to -2 (rather unsuitable), which is shown schematically in Figure 3. This is designed to anticipate that an unfavourable expression with regard to just one variable can already markedly affect the suitability of the location. The assessment was based on expert knowledge as well as on specific literature studies $[19,23,40,54]$. For example, due consideration was given to the fact that a measure such as extensification of grassland may have an impact on feed value and that this option may not be optimal in municipalities with a high volume of dairy farming [55].

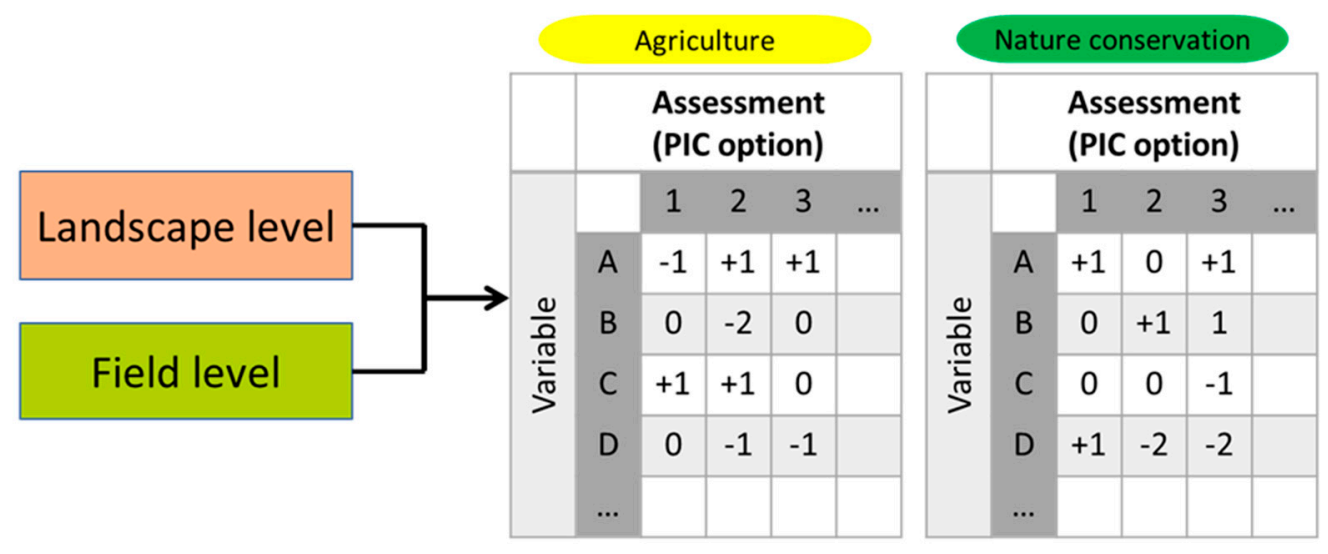

Figure 3. Schematic representation of the valuation of the PIC options in the assessment matrix.

\subsection{Plot-Specific Evaluation of the PIC Options}

The above-mentioned evaluations of the PIC options by variable were then used in an algorithm to generate the map in $\mathrm{R}$ [56]. In the algorithm, the value $(1 ; 0)$ of all 31 variables was recorded for each plot, and the evaluation result was calculated for each PIC option on 
each plot as the sum of the products of the value, of the variable and the evaluation in the assessment matrix, according to the example in Table 5.

Table 5. Example calculation of the evaluation of a measure (permanent flower strips from a nature conservation point of view) on a specific field in the model using the field-level variables.

\begin{tabular}{|c|c|c|c|}
\hline Variable & $\begin{array}{l}\text { Presence of the Feature } \\
\text { (Binary Variable) }\end{array}$ & $\begin{array}{l}\text { Evaluation in the Matrix } \\
\text { (Integer Variable) }\end{array}$ & $\begin{array}{c}\text { Evaluation of the Measure } \\
\text { on the Plot } \\
\text { (Integer Variable) }\end{array}$ \\
\hline Forest $(\leq 20 \mathrm{~m}$ distance $)$ & 0 (no) & -1 & 0 \\
\hline Water bodies ( $\leq 20 \mathrm{~m}$ distance) & 1 (yes) & -1 & -1 \\
\hline Biotopes ( $\leq 20 \mathrm{~m}$ distance) & 1 (yes) & +1 & +1 \\
\hline $\begin{array}{l}\text { Woody structures } \\
\text { ( } \leq 20 \text { m distance })\end{array}$ & 1 (yes) & +1 & +1 \\
\hline $\begin{array}{l}\text { Wetland areas } \\
(\leq 20 \mathrm{~m} \text { distance })\end{array}$ & 0 (no) & +1 & 0 \\
\hline Dry areas ( $\leq 20 \mathrm{~m}$ distance $)$ & 0 (no) & +1 & 0 \\
\hline Soil quality (low) & 0 (no) & 0 & 0 \\
\hline Soil quality (high) & 1 (yes) & +1 & +1 \\
\hline $\begin{array}{c}\text { Within nature conservation } \\
\text { area (yes) }\end{array}$ & 0 (no) & +1 & 0 \\
\hline $\begin{array}{c}\text { Within Natura } 2000 \text { network } \\
\text { (yes) }\end{array}$ & 1 (yes) & +1 & +1 \\
\hline $\begin{array}{c}\text { Groundwater and backwater } \\
\text { up to } 1 \mathrm{~m} \text { depth (yes) }\end{array}$ & 0 (no) & -2 & 0 \\
\hline Risk of soil erosion (yes) & 0 (no) & 0 & 0 \\
\hline Sum & & & +3 \\
\hline
\end{tabular}

In addition to the assessment described above, the current level of intensification is also important for the PIC option extensification of grassland. Based on the information in the IACS dataset, certain grassland areas were excluded from this option because they are most likely already in extensive use. Consequently, grassland areas with agri-environmental measures, orchard meadows, sheep pastures, set-aside permanent grassland areas, or biotopes with grassland use were excluded. Hence, the option was set at zero in the total evaluation of the plot.

\subsection{Generation of the Regional PIC Map}

Based on the total evaluation, according to Section 3.5, each PIC option was then given two ratings on each plot from an agricultural and nature conservation point of view, for example, from zero to 16 for permanent flower strips from a nature conservation perspective. Since we focused on a regional map, one aim was to select the most suitable plots for the PIC options in the region. Therefore, for each PIC option, the plots with assessment values above the $75 \%$ quantile in relation to the entire region were filtered (e.g., scoring $>5$ for permanent flower strips). As the assessment values are integer numbers, it is possible that more than $25 \%$ of the plots were considered in this way. The remaining plots were then attributed the value " 0 " for the specific PIC option. This ensures that plots in the region, that are particularly suitable for a PIC option, are represented in the map. Afterwards, the PIC option with the highest score per plot was selected. In the case of the attribution of zero for all PIC options, no option is recommended in the map. In the evaluation, of course, several options were sometimes close to each other. Therefore, to encourage a compromise between agriculture and nature conservation and allow a margin for potential on-site coordination, almost equivalent options should be proposed in some cases. However, the proposed options should not be too general. In this context, Table 6 analyses the range between the best, second best PIC option etc. (1. Max, 2. Max ... ) with mean, median, and the $25 \%$ quantile. For this analysis, all plots were considered where at 
least one option had a higher rating than zero. Based on this, a delta of 3 was selected as the cut-off value for recommending an option.

Table 6. Consideration of the delta between options using the example of the nature conservation perspective, restricted to plots where at least one option is valued higher than zero (1. Max $>0)$.

\begin{tabular}{cccc}
\hline Range & Mean Difference & Median & Q25-Quantil \\
\hline 1. Max and 2. Max & 4.3 & 1 & 0 \\
1. Max and 3. Max & 5.1 & 4 & 1 \\
1. Max and 4. Max & 5.9 & 5 & 3 \\
1. Max and 5. Max & 7.8 & 8 & 6 \\
1. Max and 6. Max & 8.1 & 8 & 6 \\
1. Max and Min & 8.1 & 8 & 6 \\
\hline
\end{tabular}

The process described above was carried out from the point of view of both nature conservation and agriculture (Figure 4). Finally, there might be one, several, or even no suggestions for PIC on a specific plot for both sides. The plots and proposed options could be displayed in a GIS-map. Based on the two-sided recommendations for PIC options, it was now possible to identify the overlaps between the agricultural and nature conservation perspectives.

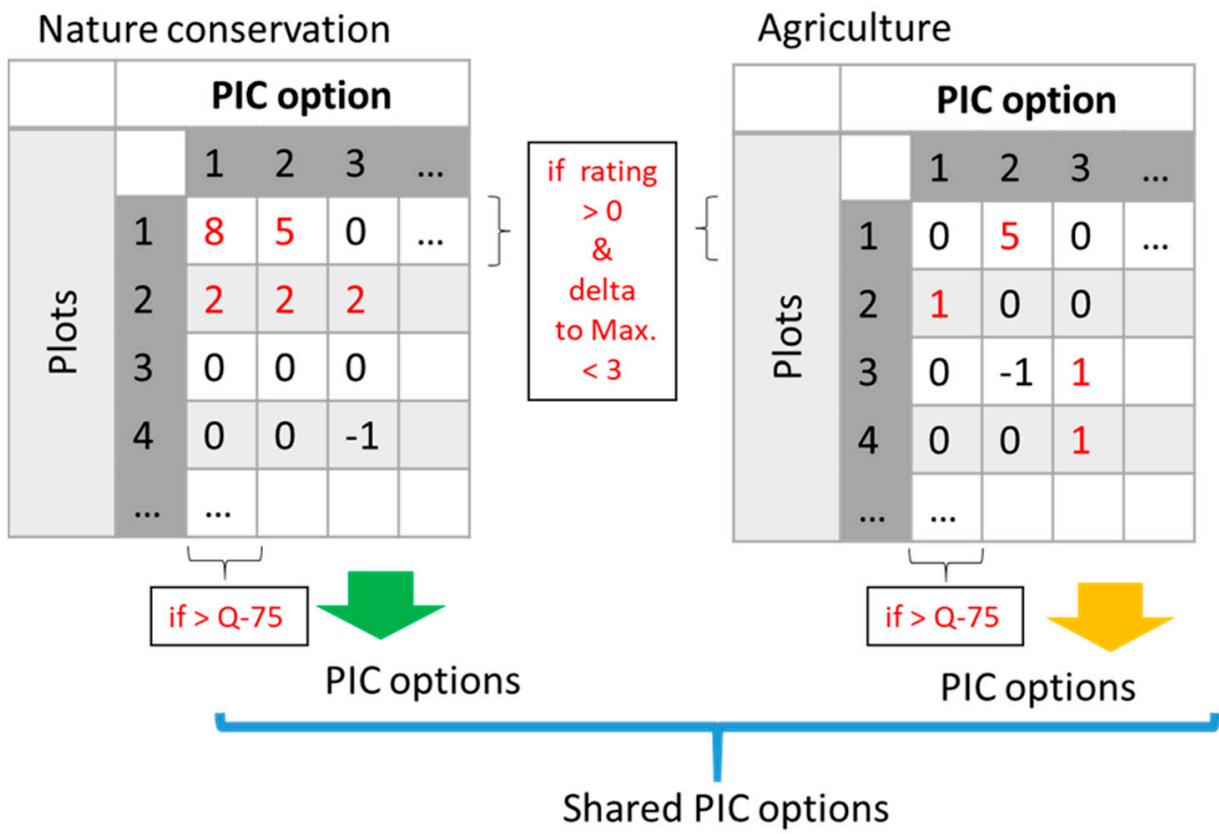

Figure 4. Derivation of plot-specific PIC option recommendations from a nature conservation and agricultural point of view based on the plot-specific overall assessment.

\section{Results}

PIC Map for the Stuttgart Region

From the perspective of nature conservation, approximately $93 \%$ of the arable land and $69 \%$ of grassland in the Stuttgart Region seem to be suitable for implementation of at least one of the considered PIC options (Table 7). Especially in the urban district of Stuttgart, almost $100 \%$ of arable land and grassland would be suitable for PIC. 
Table 7. Proportion of arable land and grassland in $\%$ and in ha that is suitable for the implementation of PIC from the perspective of nature conservation.

\begin{tabular}{ccccc}
\hline & \multicolumn{3}{c}{ Land with at Least One Suggested Option from the Perspective of Nature } \\
Conservation \\
Urban/Rural \\
\cline { 2 - 5 } District & \multicolumn{2}{c}{ Proportion in \% } & \multicolumn{2}{c}{ In ha } \\
\cline { 2 - 5 } & Arable Land & Grassland & Arable Land & Grassland \\
\hline Böblingen & 78.3 & 58.2 & 11,584 & 4282 \\
Esslingen & 96.8 & 58.2 & 9375 & 5539 \\
Göppingen & 95.6 & 75.6 & 11,479 & 11,804 \\
Ludwigsburg & 96.0 & 74.7 & 22,516 & 3912 \\
Rems-Murr- & 97.0 & 71.1 & 10,825 & 8824 \\
Kreis & 100 & 95.6 & 1330 & 656 \\
Stuttgart & 92.7 & 68.9 & 67,110 & 35,016 \\
\hline Stuttgart Region & &
\end{tabular}

Figure 5 shows the PIC map from the nature conservation perspective. The option with the highest rating, or no option, is presented for each plot in the map. Should two measures have an equally high rating, they were presented according to a fixed ranking, ranging from permanent flower strips, flower strips, grassland, extensive used arable land, fallow land, reduced tillage, to temporary greening. The map clearly shows the described agricultural structural features of the region. Hence, for instance in the district of Ludwigsburg with more than $75 \%$ utilised arable land (UAA), the extensification of arable land is the major recommended option. In addition, the share of specialty crops there is rather low, and it is mainly cereals that are grown. In the centre of the region, the implementation of permanent flower strips is particularly recommended. The ecological success of flower strips is rather independent of soil quality, and therefore more suitable in areas with very high soil quality, for instance, in Stuttgart. The districts of Göppingen und Rems-Murr-Kreis are characterised by a high proportion of grassland. Consequently, extensification of grassland is also a frequently suggested option in these areas.

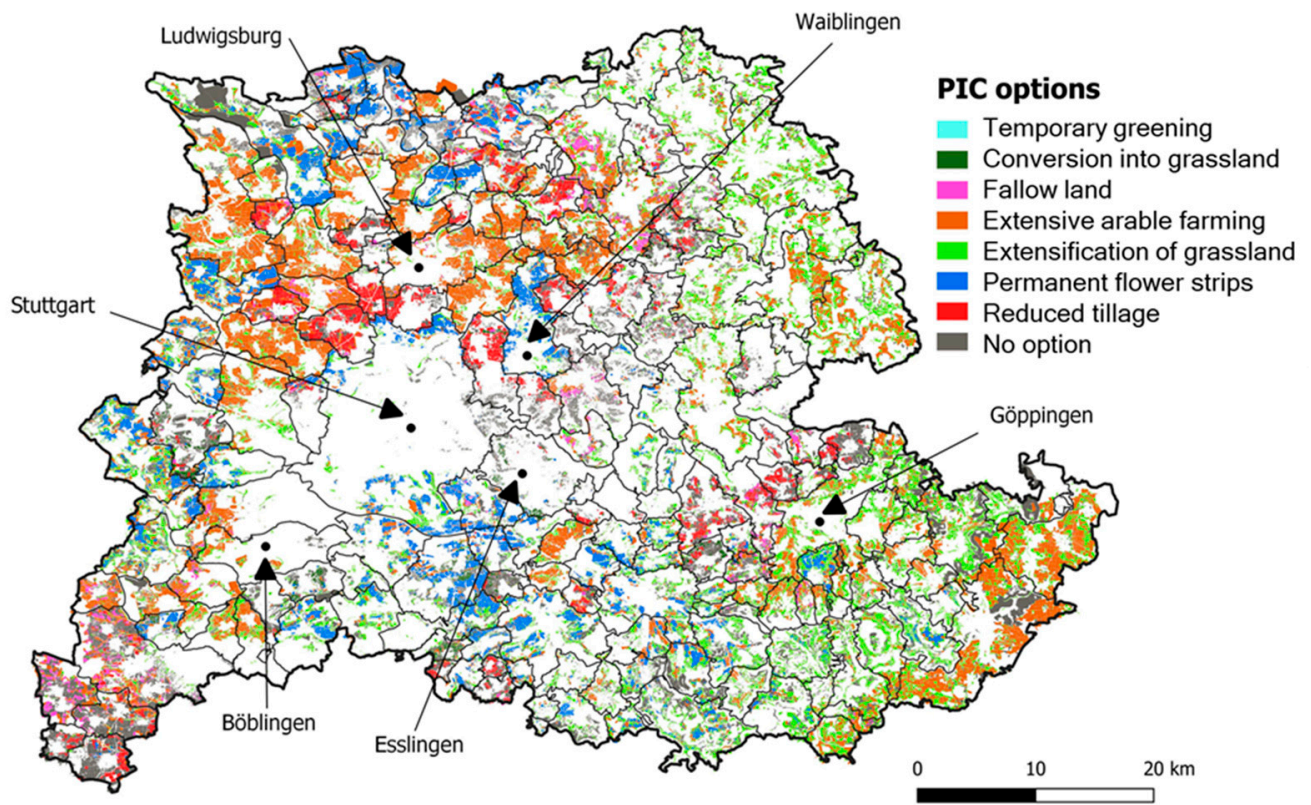

Figure 5. PIC map from the nature conservation perspective showing the priority option based on IACS data and BKG [36].

Generally speaking, PIC is often less recommended from the perspective of agriculture than from the nature conservation perspective. Furthermore, there are also clear regional 
disparities. For example, from an agricultural point of view, only about $25 \%$ of the areas in Stuttgart would be suitable for PIC. This constitutes a considerable discrepancy vis-a-vis the nature conservation assessment (Table 8).

Table 8. Proportion of arable land and grassland in $\%$ and in ha that is suitable for the implementation of PIC from the perspective of agriculture.

\begin{tabular}{ccccc}
\hline & \multicolumn{3}{c}{ Land with at Least One Suggested Option from the Perspective of } \\
Ugriculture \\
\cline { 2 - 5 } Urban/Rural & \multicolumn{3}{c}{ Proportion in \% } & \multicolumn{2}{c}{ In ha } \\
\cline { 2 - 5 } & Arable Land & Grassland & Arable Land & Grassland \\
\cline { 2 - 5 } & 79.2 & 50.4 & 11,718 & 3709 \\
Böblingen & 76.3 & 50.3 & 7392 & 4796 \\
Esslingen & 86.1 & 47.8 & 10,347 & 7459 \\
Göppingen & 82.9 & 46.7 & 19,445 & 2447 \\
Ludwigsburg & 82.8 & 42.4 & 9247 & 5257 \\
Rems-Murr- & 24.2 & 95.6 & 321 & 656 \\
Kreis & 80.7 & 47.8 & 58,470 & 24,325 \\
Stuttgart & &
\end{tabular}

In addition, the suggested options may differ between the agricultural and nature conservation perspective. Especially from the point of view of agriculture, the option of temporary greening is seen as a preferred option according to the model (Figure 6). There are also spatial differences within the region. In the western part of the region, temporary greening is often the preferred option, while in the centre and eastern part of the region, reduced tillage and extensification of grassland are often recommended.

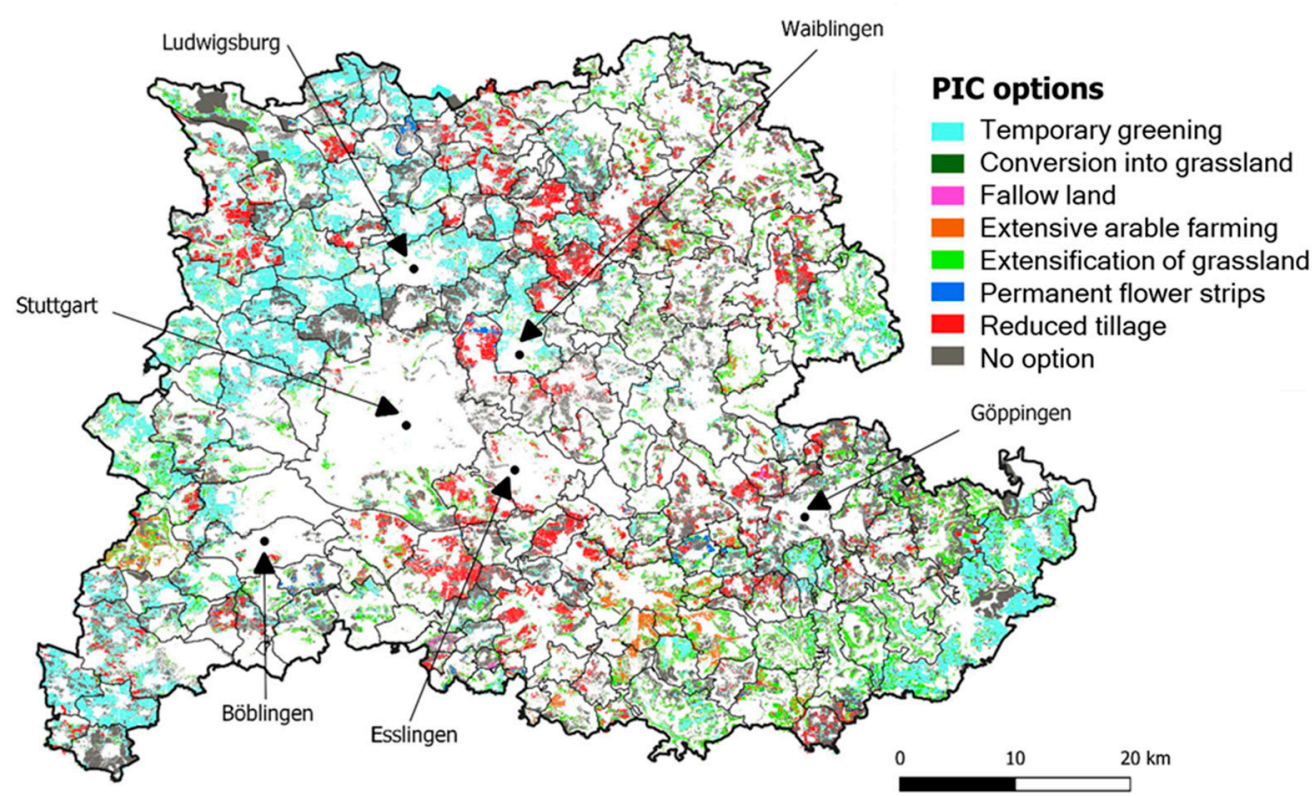

Figure 6. PIC map from the agricultural perspective illustrating the priority option based on the IACS data and BKG [36].

However, there are also overlaps between the nature conservation and agricultural assessments. This applies to about $13 \%$ of arable land and $43 \%$ of grassland. In this context, there are clear spatial disparities between the districts. Whereas in Esslingen, more than $23 \%$ of arable land would be suitable for the implementation of PIC, but in Stuttgart, this figure is only $0.1 \%$ of the arable land. Nevertheless, there seems to be a potential for PIC measures on grassland in the district of Stuttgart (Table 9). 
Table 9. Proportion of arable land and grassland in $\%$ and in ha that is suitable for the implementation of PIC from the perspective of both nature conservation and agriculture.

\begin{tabular}{ccccc}
\hline \multirow{2}{*}{$\begin{array}{c}\text { Urban/Rural } \\
\text { District }\end{array}$} & \multicolumn{3}{c}{$\begin{array}{c}\text { Land with at Least One Shared Suggested Option from the Perspective of } \\
\text { Agriculture and Nature Conservation }\end{array}$} \\
\cline { 2 - 5 } & \multicolumn{2}{c}{ Proportion in \% } & \multicolumn{2}{c}{ In ha } \\
\cline { 2 - 5 } & Arable Land & Grassland & Arable Land & Grassland \\
\hline Böblingen & 12.3 & 43.6 & 1818 & 3209 \\
Esslingen & 23.8 & 46.7 & 2309 & 4449 \\
Göppingen & 15.5 & 45.5 & 1857 & 7112 \\
Ludwigsburg & 6.8 & 43.0 & 1605 & 2256 \\
Rems-Murr- & 18 & 34.4 & 2005 & 4275 \\
Kreis & 0.1 & 95.6 & 9 & 656 \\
Stuttgart & 13.3 & 43.2 & 9602 & 21,956 \\
\hline Stuttgart Region & & &
\end{tabular}

Figure 7 shows these overlaps, i.e., land plots with a potential for PIC from both the nature conservation and agricultural perspective on arable land and grassland. Accordingly, the potential for PIC seems to be higher, in terms of area, in the east of the region than in the western districts.

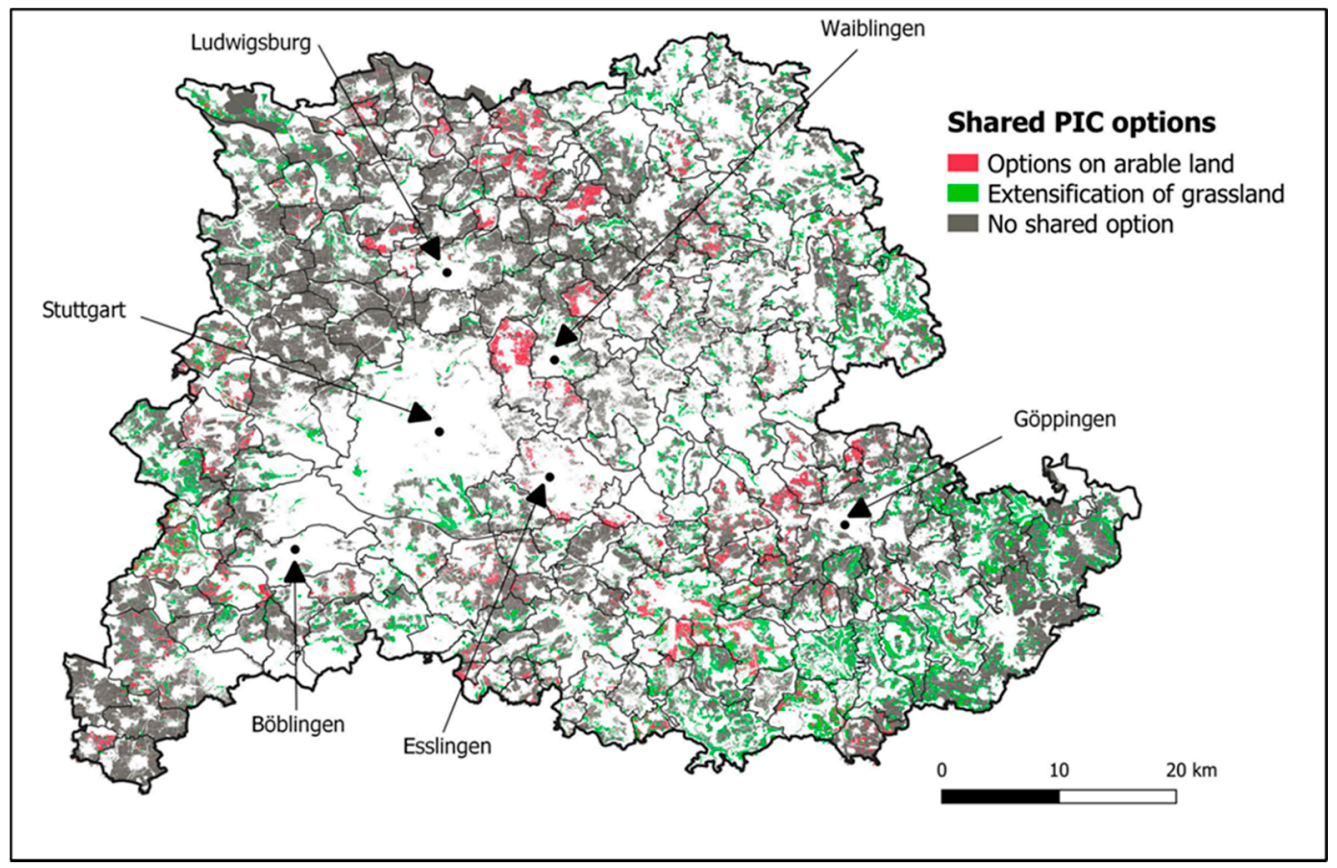

Figure 7. PIC map from both the nature conservation and agricultural perspective based on the IACS data and BKG [36].

On average, 0.23 PIC options per plot are recommended from both a nature conservation and an agricultural perspective. As described in Section 3.6, for each PIC option the plots were selected where the score was above the $75 \%$ quantile related to the region. Using the $60 \%$ quantile, there are, on average, 0.25 shared PIC options per area. At the $90 \%$ quantile, the average number of shared PIC options drops to 0.20 per plot. This sensitivity results specifically from the perspective of the nature conservation assessment since, in the context of the agricultural assessment, Q-60, Q-70, and Q-90 are identical with the exception of temporary greening. 


\section{Discussion}

\subsection{Case-Study Application Using the Example of Filderstadt for the Plausibility Check}

To prove plausibility, the regional map was applied to individual landscape sections in the urban area of Filderstadt as part of the Stuttgart Region (Figure 8). In the process, the map was assessed by an expert using various aerial photographs and specific site knowledge. Overall, the map yielded plausible recommendations for PIC measures from both a nature conservation and an agricultural perspective. Nevertheless, minor adjustments are worth considering. For example, from a nature conservation perspective, the "conversion to grassland" measure might generally be the first choice over flower strips, especially as a buffer to water bodies (Figure 6). In addition, not all grassland plots with extensive land use seem to be covered, as the data are based on the IACS. Therefore, not all arable and grassland plots are considered, for instance, private land for which no direct payments have been applied for. Furthermore, it might also make sense to recommend the conversion of arable land to grassland in the vicinity of FFH meadows (e.g., $50 \mathrm{~m}$ ) from a nature conservation perspective. In summary, the conclusion is positive, although minor adjustments are worth considering. Grassland in the floodplain is typical for central Europe. The locations in valleys are often too damp for arable farming or they flood annually, for instance [57-59]. Grassland protects the waterbodies against the entry of phosphate, nitrate, or pesticides. In addition, grassland can prevent soil erosion, serve as a habitat for numerous endangered species, and is important for the biotope network, for instance [60-62].

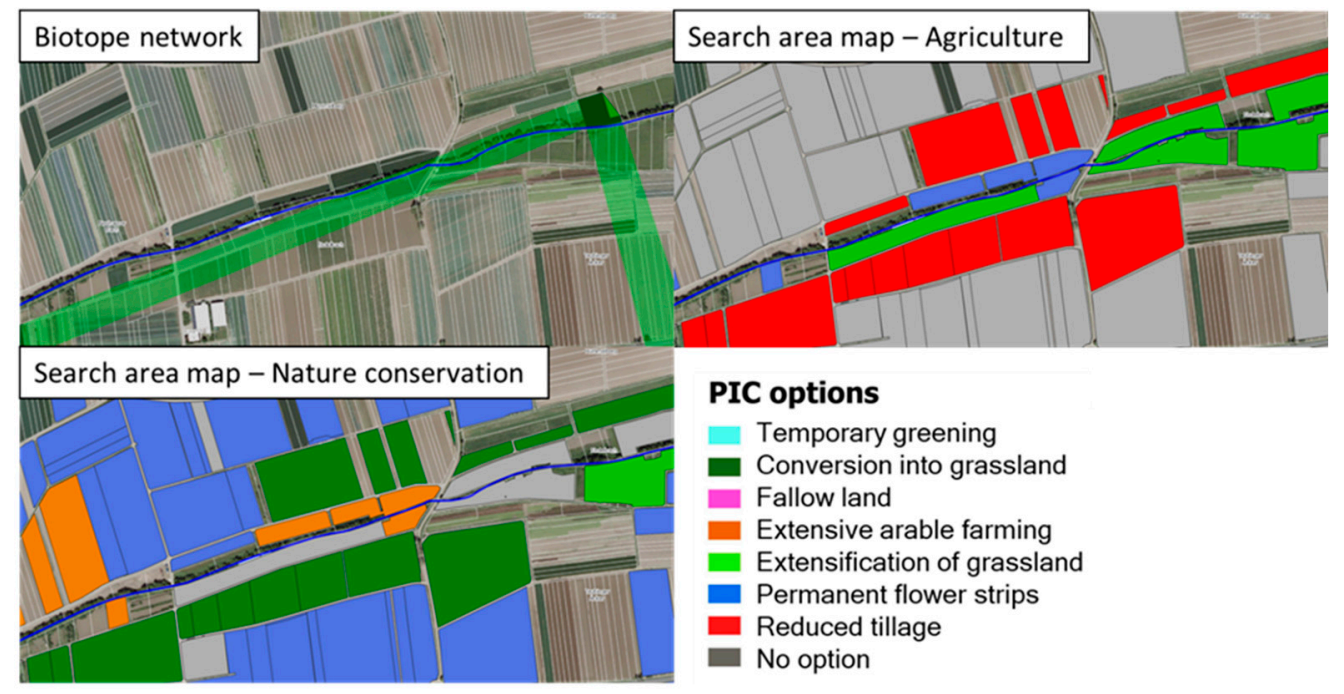

Figure 8. Application of the regional map using the example of an agricultural landscape segment in Filderstadt based on the IACS data and LUBW [63].

\subsection{Discussion of the Approach}

Based on the hypothesis that there may well be synergies between agricultural interests and conservation objectives in the planning of compensation measures, we produced a regional map for production-integrated compensation measures. We found that, in terms of suitable areas and measures, there is indeed a relevant overlap. This can, therefore, confirm our hypothesis. According to our model, there is significant implementation potential for PIC on more than $10 \%$ of arable land and more than $40 \%$ of grassland from a nature conservation and agricultural perspective. However, we also identified conflicting interests between nature conservation and agriculture. On the one hand, the PIC option of temporary greening permits good integration into crop rotation, for instance by greening tramlines. It, therefore, offers a high degree of flexibility from an agricultural point of view. On the other hand, this option is viewed critically from a nature conservation perspective as it can have a trapping effect on insects. In addition, we also found spatial disparities 
within the region. From an agricultural point of view, PIC measures may be less attractive in the centre of the region, due to a high proportion of specialty crops in the crop rotation with correspondingly high gross margins and high soil quality. This supports the findings of Sponagel et al. [41]. Furthermore, the municipalities in the district of Ludwigsburg have an average share of more than $10 \%$ of root crops in the crop rotation, which is markedly above the average for the region and may help explain the regional disparities. In this context, the distribution of protected areas under nature conservation law is also relevant, which differs between the districts. In Ludwigsburg, for example, in the average of all municipalities, almost $5 \%$ of arable land are located in FFH areas, whereas, in the RemsMurr-Kreis, this is below $1 \%$. All in all, there are many potential indicators that influence the spatially differentiated recommendation of PIC-options. In addition, the extensification of grassland might often be a less favourable option due to the reduced amount and quality of fodder [64]. In the context of PIC implementation in practice, it should also be mentioned that the costs of PIC measures may differ in the end due to different land prices. In general, measures require legal certainty, for instance, in the form of a land register entry, which can go hand in hand with a loss of market value of the land plot [65]. Especially in the centre of the Stuttgart Region, land prices for arable land are comparatively high, which might be challenging for the implementation of measures, especially from an agricultural perspective $[41,66]$.

We used relevant, available geospatial data to evaluate the PIC options. In particular, protected areas under nature conservation law, biotope networks and landscape elements were included in the analysis from a nature conservation perspective. From an agricultural perspective, one focus was on the proportions of individual crop types in the crop rotation, such as root crops or cereals, soil quality as an indicator of the yield capacity of the plots, and data on livestock density. The crop sequence influences, for example, the option of arable extensification, which is less recommended from an agricultural point of view if the share of root crops is high [54]. In addition to variables at the landscape level, variables at the field level were also considered. For example, from an agricultural perspective, the proximity of a parcel to a forest edge, water body, or other landscape feature may be associated with management constraints and may predispose the location for PIC implementation. There may be restrictions on the use of pesticides and fertilisers, for example. With the arrival of the Act amending the Nature Conservation Act (NatSchG) and the Act concerning agriculture and landscape management $(L L G)$ from 22 July 2020 in Baden-Württemberg, future restrictions on the use of plant protection products in protected areas were also adopted. In this context, avoiding the use of chemical pesticides can result in yield losses of about $30 \%$ for winter wheat, for example [67]. Therefore, future potential farming restrictions may lower the revenue of agricultural production. In addition, protected areas under nature conservation law often already have a negative impact on land prices $[65,68]$. In this respect, it can be assumed that the obstacle to implementation of PIC from an agricultural point of view is lower in these cases than in other areas with high productivity and suitability for special crops, etc. In addition, marginal sites with low yield capacity can be generally regarded as appropriate from an agricultural perspective. From the point of view of nature conservation, the strengthening of biotope networks and protected areas is also an important concern. Furthermore, from a nature conservation point of view, lean sites are often suitable for the establishment of fields with wild herbs or species-rich grassland [69]. This overlap of interests is thus also reflected in the model. In the future, for example, the management plans for Natura 2000 sites could be integrated into the model that set development targets for specific areas. In this way, further information related to the specific plot could be integrated.

In addition, it might be worthwhile to also address interests such as regional food supply with regard to the implementation of PIC measures in future studies. On the one hand, measures such as the extensification of arable land might enable further agricultural land use. On the other, they may be linked to rather high yield losses and respective low contributions to food supply [70]. Consequently, the relationship between the improvement in 
terms of nature conservation and land occupation is also relevant. In Baden-Württemberg, biodiversity offsets for habitat banking are assessed in eco credits, for example [71].

Some simplifications had to be made when selecting the PIC measures and bundling them into eight options. In addition, there are measures such as short-rotation plantations that were not taken into account because they could not be adequately assessed on the basis of the available data and are also under discussion [72]. Furthermore, there are definitely relevant criteria that could not be taken into account due to poor data availability. When planning measures, the possible presence of rare arable wild herbs, for example, should be checked on site. In addition, the presence of certain species such as partridges (Perdix perdix) should be examined on site. In this case, measures such as flower strips in particular would be an appropriate option, although this may not be apparent from the model [73].

Although our regional map is designed for intervention regulation under nature conservation law, there are, of course, parallels to agri-environmental measures or similarities with measures such as flower strips. Biotope connectivity, in particular, is an important political goal that is defined in section $22 \mathrm{NatSchG}$ and can be supported by our model. In Baden-Württemberg, in particular, the biotope network is to be expanded to $15 \%$ of open land by 2030, and refugial areas are to be created on $10 \%$ of agricultural land. Hence, cooperation with agriculture will probably be necessary. Consequently, the activities of individual farmers should be coordinated at the landscape level in order to ensure the delivery of certain ecosystem services [74]. Ecological networks, particularly on a regional level are, therefore, essential for the preservation of biodiversity [75].

Furthermore, this study could not take into account acceptance of the measures. Some farmers may also reject PIC measures outright. In this context, the required compensation payment for the measures may, of course, vary as well [19]. The strength of our model is, therefore, that it can identify the options that have the highest probability of being implemented on the land.

As our study refers specifically to agricultural land, integration into other models or extension is possible at any time. This also allows for adaptation to possibly deviating local conditions. In this way, our model also ties in with other studies that deal with modelling the ecological effectiveness of biodiversity offsets at the landscape level $[76,77]$.

\subsection{Feedback from a Stakeholder Workshop}

At a workshop on production-integrated compensation within the project RAMONA, as part of the BMBF funding activity Stadt-Land-Plus, the developed PIC map was presented in January 2021 to more than 25 participants from the agricultural and nature conservation administration, relevant ministries, the agricultural professional representation in Baden-Württemberg, as well as cultural land foundations from various other federal states. One question that was raised had to do with whether such a map could contribute to the improved establishment of PIC measures in practice. Of the 21 respondents, $96 \%$ answered this in the affirmative, illustrating the need and potential opportunities for a PIC map.

Nevertheless, in the context of the application of such a regional PIC map, essential criteria were mentioned by the participants from agriculture. Firstly, a regional map must not lead to a top-down change in agricultural land use. Secondly, agriculture must always be able to participate in the decision-making process. On-site communication, therefore, plays a central role.

Furthermore, it was mentioned that such a regional map could be helpful especially for municipalities that own a lot of agricultural land in order to come up with reasonable solutions for all the parties involved. In this respect, the map could also serve as a basis for discussing the implementation of PIC. Ultimately, of course, the current land use and the species and habitat endowment on site must be assessed and taken into account. In addition, other existing nature conservation objectives such as the biotope network and existing measures in the surrounding area must be considered. This also includes any 
land uses in the surrounding area that could have a negative impact on the success of the offset measure.

\subsection{Provision of the PIC Map in a Web Application}

The generated regional map is to be made available by the regional planning association, Verband Region Stuttgart, in a web application. This is intended for municipalities in particular. Within the application, suggestions from an agricultural and nature conservation point of view can be retrieved for each plot in the region. Furthermore, it should be possible to display suitable plots for specific PIC options or plots with an overlap between proposals from an agricultural and nature conservation perspective.

\section{Conclusions}

Geodata were used to create a regional map for production-integrated compensation measures that will be made available for practical use. We found that there may be significant potential for PIC in the Stuttgart Region from an agricultural and nature conservation perspective. The map can thus provide an initial overview when planning and designing biodiversity offsets on farmland. On a regional level, structures for networking and bundling measures can be derived. This can improve the ecological effectiveness of biodiversity offsets. All in all, the final decision on the type of offset measure to be implemented can and must always be made on site. However, in the dialogue between the intervening party, for instance a municipality and a farmer, the map can serve as a foundation for a constructive discussion to determine acceptable solutions for both nature conservation and agriculture. Our regional map can also be integrated into other areas of nature conservation planning such as the biotope network, whereby synergy effects with nature conservation measures, on areas outside agricultural use, can be derived.

A wide range of usable geodata are available, especially for the Stuttgart Region, which could be used to the advantage of this study. In general, the approach requires environmental data such as protected areas under nature conservation law, data on the agricultural structure and land use as well as suitable soil data. Within Germany and Europe, it can be assumed that similar data are available for other regions, for instance, soil maps such as the Corine European soil database [78] or data on agricultural land use. Accordingly, there should be good transferability to individual regions outside the Stuttgart Region with comparable data availability. For this purpose, our chosen approach is generally very flexible, i.e., further variables can be added or it can be adapted for other regions. If the approach is to be transferred to other regions, it should be noted that the selection of the PIC options, the definition of the variables such as distances to water bodies etc. and, at least, the assessment of the options were based on expert knowledge with regard to the rather small-scale agricultural structures in Baden-Württemberg [79]. For regions with less structurally rich agricultural landscapes and larger field structures such as eastern Germany [80], for example, the preselected PIC options should possibly be adjusted. For example, short rotation coppice was not selected for the Stuttgart Region because of the structure of the agricultural landscape. However, it may be a potential PIC option for other regions [72]. Based on our experience, we recommend that new expert groups be set up to roll out the approach to other regions. Ideally, the groups should be made up of equal numbers of people from the field of nature conservation and the field of agriculture. These individuals should be familiar with the specific local conditions, i.e., local stakeholders such as nature conservation authorities and farmers' associations, would be the predestined interlocutors in this case. In addition, a transdisciplinary approach, with cooperation between science and practice, could be advantageous in order to represent different perspectives. From our point of view, it should also be borne in mind that an intensive exchange within an expert group may be necessary over a period of several months.

Supplementary Materials: The following are available online at https:/ / www.mdpi.com/article/10 .3390/land10080808/s1, Table S1: Assessment matrix. 
Author Contributions: Conceptualization, C.S.; Methodology, C.S., M.M. and A.R.; Software, C.S.; Validation, A.R., M.M., U.G.-K., S.Z.-O. and E.A.; Formal Analysis, C.S.; Investigation, C.S.; Resources, C.S. and E.A.; Data Curation, C.S.; Writing-Original Draft Preparation, C.S.; Writing-Review \& Editing, E.B., E.A., M.M., A.R., U.G.-K., S.Z.-O. and C.S; Visualization, C.S. and A.R.; Supervision, E.B.; Project Administration, E.A.; Funding Acquisition, E.B. All authors have read and agreed to the published version of the manuscript.

Funding: This research was funded by the German Federal Ministry of Education and Research (BMBF) within the RAMONA project (grant ID: 033L201B) as part of the funding activity Stadt-Land-Plus.

Conflicts of Interest: The authors declare no conflict of interest.

\section{References}

1. Fletcher, R.J., Jr.; Didham, R.K.; Banks-Leite, C.; Barlow, J.; Ewers, R.M.; Rosindell, J.; Holt, R.D.; Gonzalez, A.; Pardini, R.; Damschen, E.I.; et al. Is habitat fragmentation good for biodiversity? Biol. Conserv. 2018, 226, 9-15. [CrossRef]

2. IPBES. Summary for Policymakers of the Global Assessment Report on Biodiversity and Ecosystem Services of the Intergovernmental Science-Policy Platform on Biodiversity and Ecosystem Services; Díaz, S., Settele, J., S, E.S.B.E., Ngo, H.T., Guèze, M., Agard, J., Arneth, A., Balvanera, P., Brauman, K.A., Butchart, S.H.M., Eds.; IPBES Secretariat: Bonn, Germany, 2019; 56p.

3. Laurance, W.F.; Peletier-Jellema, A.; Greenen, B.; Koster, H.; Verweij, P.; van Dijck, P.; Lovejoy, T.E.; Schleicher, J.; van Kuijk, M. Reducing the global environmental impacts of rapid infrastructure expansion. Curr. Biol. 2015, 25, 259-262. [CrossRef] [PubMed]

4. GIBOP. Global inventory of biodiversity offset policies (GIPOP). In International Union for Conservation of Nature: The Biodiversity Consultancy; Durrel Institute of Conservation \& Ecology: Canterbury, UK, 2019.

5. Bull, J.W.; Strange, N. The global extent of biodiversity offset implementation under no net loss policies. Nat. Sustain. 2018, 1, 790-798. [CrossRef]

6. Albrecht, J.; Schumacher, J.; Wende, W. The German Impact-Mitigation Regulation. Environ. Policy Law 2014, $44,317-333$.

7. Arlidge, W.N.S.; Bull, J.W.; Addison, P.F.E.; Burggass, M.J.; Gianuca, D.; Gorham, T.M.; Jacob, C.; Shumway, N.; Sinclair, S.P.; Watson, J.E.M.; et al. A global mitigation hierarchy for nature conservation. BioScience 2018, 68, 336-347. [CrossRef]

8. Kiesecker, J.M.; Copeland, H.; Pocewicz, A.; McKenney, B. Development by design: Blending landscape-level planning with the mitigation hierarchy. Front. Ecol. Environ. 2010, 8, 261-266. [CrossRef]

9. Gelcich, S.; Vargas, C.; Carreras, M.J.; Castilla, J.C.; Donlan, C.J. Achieving biodiversity benefits with offsets: Research gaps, challenges, and needs. Ambio 2017, 184-189. [CrossRef] [PubMed]

10. Tietz, A.; Bathke, M.; Osterburg, B. Art und Ausmaß der Inanspruchnahme landwirtschaftlicher Flächen für außerlandwirtschaftliche Zwecke und Ausgleichsmaßnahmen. In Thuenen Working Papers; Johann Heinrich von Thuenen-Institut (vTI), Federal Research Institute for Rural Areas, Forestry and Fisheries: Braunschweig, Germany, 2012; p. 137038.

11. Wende, W.; Tucker, G.-M.; Quétier, F. Biodiversity Offsets: European Perspectives on No Net Loss of Biodiversity and Ecosystem Services; Springer International Publisher: Cham, Switzerland, 2018; ISBN 9783319725819.

12. Le Coent, P.; Préget, R.; Thoyer, S. Compensating Environmental Losses Versus Creating Environmental Gains: Implications for Biodiversity Offsets. Ecol. Econ. 2017, 142, 120-129. [CrossRef]

13. Umweltbundesamt. Struktur der Flächennutzung. Available online: https://www.umweltbundesamt.de/daten/flaeche-bodenland-oekosysteme/flaeche/struktur-der-flaechennutzung\#die-wichtigsten-flachennutzungen (accessed on 10 January 2021).

14. Koh, N.S.; Hahn, T.; Boonstra, W.J. How much of a market is involved in a biodiversity offset? A typology of biodiversity offset policies. J. Environ. Manag. 2019, 232, 679-691. [CrossRef]

15. Taherzadeh, O.; Howley, P. No net loss of what, for whom?: Stakeholder perspectives to Biodiversity Offsetting in England. Environ. Dev. Sustain. 2018, 20, 1807-1830. [CrossRef]

16. Vaissière, A.C.; Tardieu, L.; Quétier, F.; Roussel, S. Preferences for biodiversity offset contracts on arable land: A choice experiment study with farmers. Eur. Rev. Agric. Econ. 2018, 45, 553-582. [CrossRef]

17. Busse, M.; Heiterpriem, N.; Siebert, R. The Acceptability of Land Pools for the Sustainable Revalorisation of Wetland Meadows in the Spreewald Region, Germany. Sustainability 2019, 11, 4056. [CrossRef]

18. Druckenbrod, C.; Beckmann, V. Production-Integrated Compensation in Environmental Offsets-A Review of a German Offset Practice. Sustainability 2018, 10, 4061. [CrossRef]

19. Czybulka, D.; Hampicke, U.; Litterski, B. (Eds.) Produktionsintegrierte Kompensation: Rechtliche Möglichkeiten, Akzeptanz, Effizienz Und Naturschutzgerechte Nutzung; Erich Schmidt: Berlin, Germany, 2012; ISBN 3503138323.

20. Druckenbrod, C.; van Elsen, T.; Hampicke, U. Produktionsintegrierte Kompensation: Umsetzungsbeispiele und Akzeptanz: Ackerwildkrautschutz mit Hilfe der Eingriffsregelung sowie Ergebnisse einer Befragung von Akteuren. Nat. Landsch. 2011, 43, 111-116.

21. Mössner, R. Produktionsintegrierte Kompensationsmaßnahmen in der Landwirtschaft. Landinfo 2019, 16-20.

22. Gullino, P.; Battisti, L.; Larchner, F. Linking Multifunctionality and Sustainability for Valuing Peri-Urban Farming: A Case Study in the Turin Metropolitan Area (Italy). Sustainability 2018, 10, 1625. [CrossRef] 
23. Etterer, F.; Fritzsch, S.; Lau, M. Arbeitshilfe Produktionsintegrierte Kompensation: Empfehlungen für die Praxis AUS Dem Forschungsvorhaben Stadt PARTHE Land. Available online: https://www.researchgate.net/profile/Florian_Etterer/ publication/341540667_Arbeitshilfe_Produktionsintegrierte_Kompensation/links/5ec62ef6458515626cbbfecb/ArbeitshilfeProduktionsintegrierte-Kompensation.pdf (accessed on 28 January 2021).

24. Zasada, I. Multifunctional peri-urban agriculture-A review of societal demands and the provision of goods and services by farming. Land Use Policy 2011, 28, 639-648. [CrossRef]

25. European Commission. Communication from the Commission to the European Parliament, the Council, the European Economic and Social Committee and the Committee of the Regions: EU Biodiversity Strategy for 2030 Bringing Nature Back into Our Lives. Available online: https: / / eur-lex.europa.eu/legal-content/EN/TXT/?qid=1590574123338\&uri=CELEX:52020DC0380 (accessed on 11 October 2020).

26. European Commission. Communication from the Commission to the European Parliemant, the Council, the European Economic and Social Committee and the Committee of the Regions: A Farm to Fork Strategy for a Fair, Healthy and EnvironmentallyFriendly Food System. Available online: https: / eur-lex.europa.eu/resource.html?uri=cellar:ea0f9f73-9ab2-11ea-9d2d-01aa7 5ed71a1.0001.02/DOC_1\&format=PDF (accessed on 2 July 2021).

27. Malorgio, G.; Marangon, F. Agricultural business economics: The challenge of sustainability. Agric. Food Econ. 2021, 9, 6. [CrossRef]

28. Etterer, F.; Voges, A.C.; Fritzsch, S.; Pietsch, M. Tagungsbeitrag: Produktionsintegrierte Kompensation (PIK) im Großraum Leipzig: Mehr Vielfalt in Agrarlandschaften III Am 13. September 2016 in Magdeburg. Available online: https://stadtpartheland. de/wp-content/uploads/2017/07/MehrVielfaltAgrarlandsch-III_Tagungsbeitrag_161206final.pdf (accessed on 5 February 2021).

29. Rabenschlag, J.; Schoof, N.; Schumacher, J.; Reif, A. Evaluation der Umsetzung baurechtlicher Ausgleichsmaßnahmen: Am Fallbeispiel Schönberg bei Freiburg. Nat. Landsch. 2019, 51, 434-442.

30. PAN. Evaluation der Ökokonto-Verordnung Baden-Württemberg. Available online: https://www.lubw.baden-wuerttemberg.de/ documents /10184/389779/Evaluation_OekokontoVO_Endbericht.pdf/2aef1af9-d532-420e-bd37-747eb24270c2 (accessed on 6 October 2020).

31. Müller, F.; Bicking, S.; Ahrendt, K.; Kinh Bac, D.; Blindow, I.; Fürst, C.; Haase, P.; Kruse, M.; Kruse, T.; Ma, L.; et al. Assessing ecosystem service potentials to evaluate terrestrial, coastal and marine ecosystem types in Northern Germany-An expert-based matrix approach. Ecol. Indic. 2020, 112, 106116. [CrossRef]

32. Kopperoinen, L.; Itkonen, P.; Niemelä, J. Using expert knowledge in combining green infrastructure and ecosystem services in land use planning: An insight into a new place-based methodology. Landscape Ecol. 2014, 29, 1361-1375. [CrossRef]

33. IREUS. Entwicklung der Ländlichen Räume in Baden-Württemberg. Available online: https://lel.landwirtschaft-bw.de/pb/site/ pbs-bw-new/get/documents /MLR.LEL/PB5Documents/alr/06_Veranstaltungen_2020/pdf_Vortr\%C3\%A4ge_PM/2019_11_ 11_IREUS2.0_Abschlussbericht.pdf (accessed on 19 January 2021).

34. Dispan, J.; Koch, A.; König, T. Strukturbericht Region Stuttgart. 2019. Available online: https://www.region-stuttgart.org/ strukturbericht/ (accessed on 19 January 2021).

35. LUBW. Bodenzustandsbericht Region Stuttgart. Landesanstalt für Umwelt Baden-Württemberg: Karlsruhe. Available online: https:/ / pd.lubw.de/35192 (accessed on 21 December 2020).

36. BKG. NUTS Regions. Available online: https://gdz.bkg.bund.de/index.php/default/open-data.html?p=2 (accessed on 25 March 2020).

37. Verband Region Stuttgart. GIS-Daten aus dem Biotop-Informations- und Managementsystem (BIMS). Available online: http: / / webgis.region-stuttgart.org/Web/BIMS/ (accessed on 28 July 2021).

38. Statistisches Bundesamt. Land- und Forstwirtschaft, Fischerei Methodische Grundlagen der Agrarstrukturerhebung. 2016. Available online: https:/ / www.destatis.de/DE/Themen/Branchen-Unternehmen/Landwirtschaft-Forstwirtschaft-Fischerei/ Landwirtschaftliche-Betriebe/Publikationen/Downloads-Landwirtschaftliche-Betriebe/grundlagen-strukturerhebung-203260 5169004.pdf?_blob=publicationFile (accessed on 28 July 2021).

39. Lischka, A.; Rode, M. Umsetzung von Blühstreifen als produktionsintegrierte Kompensationsmaßnahme (PIK). Umw. Raun 2018, 9, 307-322.

40. Gödeke, K.; Schwabe, M.; Bärwolff, M.; Marschall, K.; Hering, T.; Degner, J.; Hochberg, H.; Maier, U.; Druckenbrod, C. Produktionsintegrierte Kompensation (PIK): Maßnahmenvorschläge; Thüringer Landesanstalt für Landwirtschaft: Jena, Germany, 2014.

41. Sponagel, C.; Back, H.; Angenendt, E.; Bahrs, E. Development of Supply Curves for Biodiversity Offsets on Agricultural Land-A Case Study from the Stuttgart Region. Ger. J. Agric. Econ. 2021, 70, 70-83. [CrossRef]

42. Statistisches Landesamt. Rinderbestand und -Haltungen (HIT-Auswertung). Available online: https://www.statistik-bw.de/ Landwirtschaft/Viehwirtschaft/05035050.tab?R=LA (accessed on 18 November 2020).

43. BfN. Naturschutzgebiete Deutschlands: nsg_2017.shp. Available online: https://www.bfn.de (accessed on 29 April 2020).

44. BfN. Vogelschutzgebiete Deutschlands (SPA): spa_de_2018.shp. Available online: https://www.bfn.de (accessed on 29 April 2020).

45. BfN. FFH-Gebiete Deutschlands: ffh_de_2018.shp. Available online: https://www.bfn.de (accessed on 29 April 2020).

46. BfN. Landschaftsschutzgebiete Deutschlands: lsg_2017.shp. Available online: https://www.bfn.de (accessed on 29 April 2020).

47. ESRI. ArcGIS Desktop: Release 10.5.1: Copyright ( $1995-2017$; Environmental Systems Research Institute: Redlands, CA, USA, 2016. 
48. ALKIS. Liegenschaftskataster. Available online: https://www.lgl-bw.de/unsere-themen/Produkte/Geodaten/Daten-desLiegenschaftskataster/ALKIS/ (accessed on 4 February 2021).

49. LUBW. Fließgewässernetz: Daten- und Kartendienst der LUBW. Available online: https://udo.lubw.baden-wuerttemberg.de/ public/pages/url/show.xhtml?url=https $\% 3 \mathrm{~A} \% 2 \mathrm{~F} \% 2$ Frips-dienste.lubw.baden-wuerttemberg.de $\% 2$ Frips $\% 2$ Fripsservices $\%$ 2Fapps\%2Fgeodatenexport\%2Fudo\%2Fdownload.aspx\%3Fid\%3D413 (accessed on 18 November 2020).

50. LUBW. Biotopverbund Feuchte Standorte: Daten- und Kartendienst der LUBW. Available online: https://udo.lubw. baden-wuerttemberg.de/public/api/navigatorurl/show?globalId=naturLand.Biotopverbund.nais $\% 3 \mathrm{~A} \% 24 \mathrm{SYSTEM} \%$ 7BCADENZAWEB_GEODOWNLOAD\%7Did\%3D600 (accessed on 31 July 2021).

51. LUBW. Biotopverbund Trockene Standorte: Daten- und Kartendienst der LUBW. Available online: https://udo.lubw. baden-wuerttemberg.de/public/api/navigatorurl/show?globalId=naturLand.Biotopverbund.nais $\% 3 \mathrm{~A} \% 24 \mathrm{SYSTEM} \%$ 7BCADENZAWEB_GEODOWNLOAD\%7Did\%3D600 (accessed on 31 July 2021).

52. LGRB. GeoFachdaten BW-Bodenkunde: BK 50. Available online: https://produkte.lgrb-bw.de/catalog/list/?wm_group_id=11 113\&p=geowakJJg56JWXCmuURWPIQSviDEUQ09 (accessed on 18 November 2020).

53. LGRB. Daten zur Bodenerosion in Baden-Württemberg: Stand Juli 2015. Available online: https://produkte.lgrb-bw.de/catalog/ list/?wm_group_id=11321\&p=geozUKeaX6ZyzM7iDytSxI8bS37bagxwD (accessed on 18 November 2020).

54. Meyer, S.; Leuschner, C. (Eds.) 100 Äcker Für Die Vielfalt: Initiativen zur Förderung der Ackerwildkrautflora in Deutschland; Universitätsverlag Göttingen: Göttingen, Germany, 2015; ISBN 9783863951849.

55. Hochberg, H.; Zopf, D. Untersuchungsergebnisse zur standort- und bestandesdifferenzierten Grünlandbewirtschaftung in Thüringen. In Proceedings of the 58. Jahrestag. Arb. Grünland Futterb. Geselschaft Pflanzenbauwiss, Arnstadt, Germany, 28-30 August 2014; pp. 31-40.

56. R Core Team. R: A Language and Environment for Statistical Computing. R Foundation for Statistical Computing. Available online: https: / /www.R-project.org/ (accessed on 1 March 2019).

57. Zerbe, S.; Wiegleb, G. Renaturierung Von Ökosystemen in Mitteleuropa; Springer: Berlin/Heidelberg, Germany, 2009; ISBN 978-3-662-48516-3.

58. Ellenberg, H.; Leuschner, C. Vegetation Mitteleuropas mit den Alpen; Ulmer: Stuttgart, Germany, 2010; ISBN 9783825281045.

59. Dierschke, H.; Briemle, G. Kulturgrasland: Wiesen, Weiden und Verwandte Staudenfluren; 20 Tabellen; Ulmer: Stuttgart, Germany, 2002; ISBN 9783800156412.

60. Jedicke, E. Biotopverbund: Grundlagen und Massnahmen Einer Neuen Naturschutzstrategie; 32 Tabellen; 2., überarb. und erw. Aufl.; Ulmer: Stuttgart, Germany, 1994; ISBN 3800133245.

61. Colditz, G. Auen, Moore, Feuchtwiesen; Birkhäuser: Basel, Switzerland, 1994; ISBN 9783764350192.

62. DWA-Arbeitsgruppe HW-4.3 “Dezentraler Hochwasserschutz”. Dezentrale Maßnahmen zur Hochwasserminderung; DWA-Regelwerk; DWA Deutsche Vereinigung für Wasserwirtschaft, Abwasser und Abfall: Hennef, Germany, 2015; ISBN 978-3-88721-262-9.

63. LUBW. Daten aus dem Umweltinformationssystem (UIS) der LUBW Landesanstalt für Umwelt Baden-Württemberg. Available online: https:/ / www.lubw.baden-wuerttemberg.de/umweltinformationssystem (accessed on 25 June 2021).

64. Seither, M.; Engel, S.; King, K.; Elsäßer, M. FFH-Mähwiesen Grundlagen-Bewirtschaftung-Wiederherstellung. Available online: https:/ / fortbildung-lazbw.lgl-bw.de/lazbw/webbasys/download/Shop/2018_GL_lazbw_FFH_Maehwiesen_Grundlagen. pdf (accessed on 25 May 2021).

65. Mährlein, A.; Jaborg, G. Wertminderung landwirtschaftlicher Nutzflächen durch Naturschutzmaßnahmen. Eine Bestandsaufnahme mit den Ergebnissen der HLBS-Expertenbefragung. Agrarbetrieb (AgrB) 2015, 3, 60-64.

66. Sponagel, C.; Angenendt, E.; Piepho, H.-P.; Bahrs, E. Farmers' preferences for nature conservation compensation measures with a focus on eco-accounts according to the German Nature Conservation Act. Land Use Policy 2021, 104, 105378. [CrossRef]

67. Schwarz, J.; Klocke, B.; Wagner, C.; Krengel, S. Untersuchungen zum notwendigen Maß bei der Anwendung von Pflanzenschutzmitteln in Winterweizen in den Jahren 2004 bis 2016. Gesunde Pflanz. 2018, 70, 119-127. [CrossRef]

68. Isermeyer, F.; Nieberg, H.; Banse, M. Auswirkungen aktueller Politikstrategien (Green Deal, Farm-to-Fork, Biodiversitätsstrategie 2030; Aktionsprogramm Insektenschutz) auf Land- und Forstwirtschaft sowie Fischerei; Thünen-Institut, Bundesforschungsinstitut für Ländliche Räume, Wald und Fischerei: Braunschweig, Germany, 2020.

69. Gilhaus, K.; Boch, S.; Fischer, M.; Hölzel, N.; Kleinebecker, T.; Prati, D.; Rupprecht, D.; Schmitt, B.; Klaus, V.H. Grassland management in Germany: Effects on plant diversity and vegetation composition. Tuexenia 2017, 37, 379-397.

70. Geisbauer, C.; Hampicke, U. Ökonomie Schutzwürdiger Ackerflächen: Was Kostet der Schutz von Ackerwildkräutern? Institut für Dauerhaft Umweltgerechte Entwicklung von Naturräumen der Erde (DUENE) e.V. and Georg-August-Universität Göttingen, Albrecht-vonHaller-Institut für Pflanzenwissenschaften, Abteilung Ökologie und Ökosystemforschung: Greifswald, Germany, 2012.

71. Mazza, L.; Schiller, J. CASE STUDY REPORT: The Use of Eco-Accounts in Baden-Württemberg to Implement the German Impact Mitigation Regulation: A Tool to Meet EU's No-Net-Loss Requirement?: A Case Study Report Prepared by IEEP with Funding from the Invaluable and OPERAs Projects; Institute for European Environmental Policy (IEEP): London, UK, 2014.

72. Zehlius-Eckert, W. Moderne Agroforstsysteme als Option für die produktionsintegrierte Kompensation (PIK)—Potenzial, aktuelle Situation und Verbesserungsvorschläge: In: Bäume in der Land(wirt)schaft—von der Theorie in die Praxis. Tagungsband. Mit Beiträgen des 5. Forums Agroforstsysteme 30.11. bis 01.12.2016 in Senftenberg (OT Brieske). Available online: https: / / opus4 .kobv.de/opus4-btu/files/4148/Tagungsband_5_Forum_Agroforstsysteme_PDFA.pdf\#page=25 (accessed on 6 July 2021). 
73. Buner, F.; Jenny, M.; Zbinden, N.; Naef-Daenzer, B. Ecologically enhanced areas-A key habitat structure for re-introduced grey partridges Perdix perdix. Biol. Conserv. 2005, 124, 373-381. [CrossRef]

74. Goldmann, R.L.; Thompson, B.; Daily, G.C. Institutional incentives for managing the landscape: Inducing cooperation for the production of ecosystem services. Ecol. Econ. 2007, 64, 333-343. [CrossRef]

75. Samway, M.J.; Bazelet, C.S.; Pryke, J.S. Provision of ecosystem services by large scale corridors and ecological networks. Biodivers. Conserv. 2010, 19, 2949-2962. [CrossRef]

76. Tarabon, S.; Dutoit, T.; Isselin-Nondedeu, F. Pooling biodiversity offsets to improve habitat connectivity and species conservation. J. Environ. Manag. 2021, 277, 111425. [CrossRef] [PubMed]

77. Moilanen, A.; Kujala, H.; Mikkonen, N. A practical method for evaluating spatial biodiversity offset scenarios based on spatial conservation prioritization outputs. Methods Ecol. Evol. 2020, 11, 794-803. [CrossRef]

78. European Environment Agency. Corine European Soil Database. Available online: https://www.eea.europa.eu/data-and-maps/ data/soil-type (accessed on 2 July 2021).

79. Klüter, H.; Bastian, U. Gegenwärtige Strukturen und Entwicklungstendenzen in der Brandenburger Landwirtschaft im Ländervergleich.: Endbericht. Stand Anfang Mai. 2012. Available online: https://www.agrarbuendnis.de/fileadmin/DAten_ AB/Projekt_Bodenmarkt/Material/2012_Gutachten_Prof._Klueter_Entwicklungstendenzen_brd._Landwirtschaft_03.07.2012 _gesamt-1.pdf (accessed on 6 July 2021).

80. Batáry, P.; Gallé, R.; Riesch, F.; Fischer, C.; Dormann, C.F.; Mußhoff, O.; Császár, P.; Fusaro, S.; Gayer, C.; Happe, A.-K.; et al. The former Iron Curtain still drives biodiversity-profit trade-offs in German agriculture. Nat. Ecol. Evol. 2017, 1, 1279-1284. [CrossRef] [PubMed] 